\title{
ISLAMIC SOCIAL REPORTING IN ISLAMIC BANKING: STAKEHOLDERS THEORY PERSPECTIVE
}

\author{
Inten Meutia $^{1, *}$, Devi Febrianti ${ }^{2}$ \\ ${ }^{1}$ Accounting Department Faculty Economic \\ ${ }^{2}$ Post Graduate Program University Sriwijaya
}

\begin{abstract}
This research aims to compare the level of Corporate Social Responsibility disclosure on Islamic banking in Indonesia and Malaysia. Using data from annual report in seven public Islamic banks in Indonesia and seven public Islamic banks in Malaysia, this research find that the level ISR of Islamic banking in Indonesia are better than the level ISR of Islamic banking in Malaysia. There were significant differences between the two groups were observed with respect to the all theme of reporting.
\end{abstract}

\section{Introduction}

The development of the Islamic financial industry in the world, especially Islamic banking is growing rapidly. In 2014, the Islamic banking assets reached $\$ 1,214,274$ of the total Islamic financial assets of $\$ 1,657,998$, or $73.23 \%$ [1]. The growth in the financial sector should be followed by the increasing role of Islamic banks in terms of social responsibility. [2] says that social responsibility is very pertinent for discussion on Islamic banking.

[3] explains that the form of these responsibilities is the disclosure of a social responsibility report. In the Islamic reporting viewpoint, it is expected that social concerns would be a principal factor of disclosure in annual reports. Consequently businesses are expected to be more transparent in their disclosure practices ([4], [5]).

Furthermore [6] explains that key stakeholders perceive Islamic banks to have equal social and economic roles. The common of the Islamic finance and economics literature, as well as key people concerned in the development of the industry, announce that Islamic banks and financial institutions adhere to Islamic Sharia principles of social justice and fairness, and deliver an alternative to conventional banking and finance ([7], [8], [9]). These opinions and expectations as well as the claims of the industry itself infer that Islamic banks are supposed to report base on their social activities ([10], [6] Islamic banks are supposed to disclose full information to the ummah (Muslim nation) about how their activities meet

\footnotetext{
*Corresponding author: inten26@yahoo.com
} 
Sharia' objectives and increase the wellbeing (and cohesion) of society ([11], [12], [13], [6]).

Malaysia is a country that representative of modern Islamic country caused by Internalization Islamic values in the government system. The companies in Malaysian have an experienced pressure to apply corporate government best practices internationally. One of the pressures is the amendment in the Bursa Malaysia's Listing Rules on January 2001 that requires public listed companies to disclose a narrative statement of how they applied principles of corporate governance in their organizations in their annual reports.

Regarding to Islamic Financial Insitutions, Malaysian government established the Shariah Advisory Council in 1996. The task of Shariah Advisory Council is to offer advice Securities Commission on Shariah related matter. Their tasks include providing guidance on Islamic Capital Market (ICM) transactions and activities with the aim to standardize and harmonizing implementations [15].This development has consequent to ISR, where Muslim decision-makers expect companies can meet their spiritual needs by disclosing relevant information [16].

Development of Islamic banking in Indonesia with a marked the establishment of Bank Muamalat Indonesia (BMI) in 1991. One of the functions and its role is to carry out social functions in order to assist people to prosperity. Act No. 21 of 2008 about Islamic banking article 4 points 2 states that one of the functions of the Islamic banks and Sharia Business Units (UUS) are doing a social function. The accounting standards published by AAOIFI (Accounting and Auditing Organization for Islamic Financial Institution) also states that one of the functions and the role of Islamic banks is to implement social activity.

The presence of differences in the rules regarding Islamic financial institutions in the two countries are very likely to result any differences in terms of social responsibility disclosure carried out by Islamic banks. Therefore our focus in this paper is two-fold: (1) to get prove empirically the level of corporate social responsibility disclosure in Islamic bank in Indonesia and Malaysia using Islamic Social Reporting (ISR), and (2) to analyze the difference of corporate social responsibility disclosure in Islamic bank in Indonesia and Malaysia using ISR. The paper proceeds as follows: section two provides the theoretical foundations and literature review of the study. Section three reports on the research methodology, section four discusses detail the findings of this study and their analysis, sections five provide recommendations and conclusion,

\section{Literature Review}

\subsection{Stakeholder Theory}

According to Stakeholder theory the sustainability of corporation needs the support from the stakeholders. The more powerful stakeholders, the more the company must adjust [17]. As indicated by [18] stakeholders can influence (directly or indirectly) control of assets required by the corporation. For that reason, stakeholder's domination is determined by the level of control they have over the assets.

Therefore, when stakeholders have a control to significant resources of the organization, the company is such as to react in a manner that satisfies the stakeholders. Moreover, [19] discusses that organizations select the stakeholders that they need to consider. The activities that they will choose in order to realize the desired relationship with those stakeholders. The Government is one important stakeholder for the company; therefore the company will try to make disclosures based on the rules set by the government. Therefore, it is very likely there will be a difference in terms of social responsibility disclosure in Islamic Bank caused by the differences in the rules that exist in each country. Therefore we suppose variances in disclosure level based on rules applied in each Countries. Thus, the hypothesis is: There are differences in levels of ISR between Islamic Banks in Malaysia and Indonesia. 


\subsection{Islamic Social Reporting}

[21] stated that ISR is a social reporting that involves not only a holistic expectation of the society regarding the role of companies in the community but also on spiritual perspective [16]. In ISR, the concern is not just on social justice but goes beyond reporting on the environment, minority interests and employees. This concern is appropriate with the stakeholders' theory whereby management presents information to stakeholders to maintain the success of corporate. The sustainability of company existence and success is dependent on the persistent support from the stakeholders [19]. It is, therefore, very important for the management to disclose information related to social and environmental according to the demand of the stakeholders [23].

A number of studies have surveyed CSR disclosure in Islamic bank (IBs) ([6], [10], and [24]). ([25], [10]) open up additional analysis into this space by provides an ethical identity index. For example, [6] consider the effect of Islam on the social reporting at 29 IBs in 16 countries. They found that level of social disclosure by IBs is far from their expectation (13.3\%). [24] using content analysis in analyze annual reports of seven IBs and found that level of CSRD for their sample is thirty-eighth. That is comparatively low comparing with their expectations, objective, and values of IBs.

[24] investigate whether any difference exists between the corporate social activities disclosed by using Islamic business ethics framework in the annual reports of seven Islamic banks from seven countries. The results show that only one Islamic bank out of seven Islamic banks has CSRD index above average and the issues of CSR are not of main concern for most Islamic banks.

[28] compare CSR disclosure in sixteen IBs from three different regions by using a standard supported Islamic value. They find that level of CSR information far below the expected level (49\%). [29] investigate the extent of CSRD in twenty-one IBs operational within the Gulf region. They found that the extent of social disclosure $(30 \%)$ was well below their benchmark index.

[10] investigate the disclosure of information considered crucial to Islamic ethics in business. They notice a major gap (48\%) between the disclosure and the ideal disclosure of seven IBs. They conclude that to be competitive IBs have to deliver more information to their stakeholders in order to improve good reputation in society.

[30] examine the level and factors that influence CSRD in the annual reports of fortyseven IBs from fourteen countries. They realize that CSRD is $16.8 \%$. Moreover, [31] explore CSRD in IBs in East Pakistan from 1983 till 2010 to examine the IBs' performance relating to CSR. They found that level of CSRD only 42nd. This result is supported by many studies that found a low-level CSRD for IBs (e.g., [32]).

Recently, the correlation between CSR and financial performance has been investigated in [33]. They found a poor level for CSRD (44\%). [30] also found other factors that have influences on the level of CSR disclosure in Islamic banks are the level of political and civil pressure.

Based on the above studies, none of them especially focus on differences in the level of social responsibility disclosure between Islamic Bank in Indonesia and Malaysia. Therefore, this research attempts to give a contribution to Islamic accounting literature.

\section{Research Methodology}

This study examines social responsibility reporting in 14 Islamic banks in the two countries by using ISR index. The content analysis uses to find if particular topics associated with social justice are disclosed (or not) in annual reports. The annual reports are related to the years 2010-2014 and were downloaded from the banks' web sites. 
The level of ISR in this research consisted of 43 items grouped into six topics that were adopted from Othman et al (2009). There are 6 topics namely Finance and Investment, Products/Services, Employee, Society, Environment and Corporate Governance. These topics consist of 43 items disclosure. By content analysis, each item had the value of 1 if the items were disclosed by the company. Otherwise, it was 0 .

If the entire item ISR Index disclosed in the annual report of Islamic Bank so it means that the Islamic Bank will get full score which are 43 points. After scoring process of IS Index finished to each Islamic Bank, the analysis will be do in order to know each of its social performance. After that, it will be calculated the average for each item. Social performance disclosure index calculation is formulated as follows: ISR index $=$ the number of items disclosed $\times 100 \%$ the total number of items.

Table 1. List of the Islamic Bank Sample

\begin{tabular}{|c|l|l|}
\hline No & \multicolumn{1}{|c|}{ Islamic Banks in Indonesia } & \multicolumn{1}{c|}{ Islamic Banks in Malaysia } \\
\hline 1 & Bank Muamalat Indonesia (BMI) & Public Islamic Bank Berhad (PIBB) \\
\hline 2 & Bank Syariah Mandiri (BSM) & CIMB Malaysia (CIMB) \\
\hline 3 & Bank Mega Syariah (BMS) & Bank Islam Berhad (BIB) \\
\hline 4 & Bank BNI Syariah (BNIS) & Hong Leong Islamic Bank (HLIB) \\
\hline 5 & Bank BRI Syariah (BRIS) & Affin Islamic Bank Berhad (AIBB) \\
\hline 6 & Bank Panin Syariah (BPS) & RHB Islamic Bank (RHB) \\
\hline 7 & Bank Syariah Bukopin (BSB) & Hong Leong Islamic Bank (HLIB) \\
\hline
\end{tabular}

\section{Findings}

\subsection{Disclosure Level of ISR}

Picture 1 below provides the average of ISR index scores for 2010 - 2014.

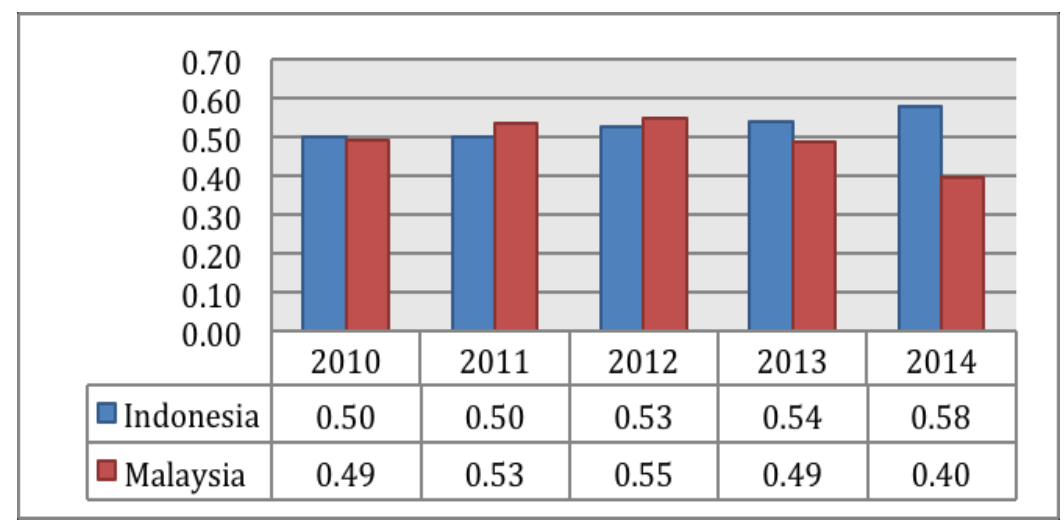

Fig 1. The ISR Index of each Country

From the figure 1, it could be seen that level ISR in Indonesia and Malaysia almost same for all year except for year 2014 Islamic bank in Indonesia gets higher level than Malaysia. ISR level in Indonesia increased from 2010 to 2014. While in Malaysia since 2012 ISR level decreases. In general, there are no Islamic banks both in Indonesia and Malaysia who fully $(100 \%)$ use index ISR to carry out their corporate social responsibility activities. This happens because of the first two possibilities. The first is that because the 
Islamic bank does not implement CSR activities. The second reason is that the Islamic banks which carry out corporate social responsibility activities, do not disclose their performances in the annual report. These empirical analyses argue that most Islamic banks both in Malaysia and Indonesia do not take serious attention for the CSR issues. Our finding consistent with many prior studies that found the low level of CSR disclosure in Islamic bank ([33], [31], [32], and [34]).

Table 2 summarizes the disclosure level for the each theme. These sections contain Finance and Investment, Product and service, employee, society, environment and corporate governance.

Table 2.

Index ISR of Islamic Banks in Indonesia and Malaysia base on each Themes

\begin{tabular}{|c|l|c|c|}
\hline No & \multicolumn{1}{|c|}{ Theme } & Indonesia & Malaysia \\
\hline 1 & Finance and Investment & 0.53 & 0.35 \\
\hline 2 & Product and Service & 0.86 & 0.66 \\
\hline 3 & Employee & 0.32 & 0.36 \\
\hline 4 & Society & 0.59 & 0.33 \\
\hline 5 & Environment & 0.17 & 0.42 \\
\hline 6 & Corporate Governance & 0.69 & 0.83 \\
\hline
\end{tabular}

Based on each theme Islamic Banks in Indonesia have higher score on the theme Finance and Investment, Product and Service and Society. While Islamic banks in Malaysia have high scores on the theme Employee, Environment and Corporate Governance. Some things that might make Islamic bank in Malaysia put more emphasis on disclosure of those themes are:

On 5 Sept 2006, Bursa Malaysia has launched CSR Framework for public-listed companies. This Framework is a guide to Malaysian companies in order to develop strategies to communicate them effectively to stakeholders through CSR. The CSR Framework focus on 4 main themes namely, environment, workplace, community and the market place.

The emphasis on Occupational Safety and Health (OSHA) for employees mandated by laws in the late nineties; the eradication of poverty; scholarships for human capital development; funds for education; non public universities; training; caring and loving society and environment protection could have motivated the level of ISR.

This is consistent with [23] that found one of the main factors why companies have a tendency to disclose more CSR information is government policy.

After the East Asian financial crisis in 1997, CSR awareness in Malaysia increased [35]. This awareness following by the Malaysian Securities Commission in the middle of 2001. Furthermore, to support this initiative CSR included by the government as one of the public policies in the National Economic Policy, the Malaysian Vision 2020 and National Integrity Plan. The most important all public listed company have to disclose CSR in the annual reports.

In the next table we try to give prove if the differences under each dimension significantly different by using $\mathrm{Z}$ test. 
Table 3. Differences Analize for Each

\begin{tabular}{|l|r|r|r|r|r|r|}
\hline & $\begin{array}{c}\text { Finance \& } \\
\text { Irvestment }\end{array}$ & $\begin{array}{c}\text { Product \& } \\
\text { Service Theme }\end{array}$ & $\begin{array}{c}\text { Employœs } \\
\text { Theme }\end{array}$ & Society Theme & $\begin{array}{c}\text { Ervironment } \\
\text { Theme }\end{array}$ & $\begin{array}{c}\text { Corporate } \\
\text { Govemance }\end{array}$ \\
\hline Mann-Whitney U & 269,500 & 340,500 & 450,500 & 177,500 & 327,000 & 290,000 \\
WilcoxonW & 899,500 & 970,500 & 1116,500 & 807,500 & 993,000 & 956,000 \\
Z & $-4,243$ & $-3,527$ & $-2,143$ & $-5,256$ & $-3,777$ & $-4,180$ \\
Asymp. Sg (2-tailed) &, 000 &, 000 &, 032 &, 000 &, 000 &, 000 \\
\hline
\end{tabular}

a Grouping Variable: Negara

Table 3 indicate that significant two-tailed is lower than 0.05. It means there were significant differences in all themes between the two countries. [36] stated that numerous laws and government regulation affect effectively every aspect of business activities.

There are numerous components which influence CSR disclosure of Islamic banks including socio-political pressures and economic incentives. [30] said that because the activity of Islamic banks is in a broader social and political environment, the interaction of power affecting the rights and responsibilities of all actors within this environment will impact the content of information and dialogue. This will consequently have an impact on the level of CSR disclosure by Islamic banks.

\section{Concluding Comments}

\subsection{Research limitations/implications}

The results of this study are subject to several limitations. The major limitation of this paper is the small sample size of only 14 Islamic banking institutions from 2 countries. Future studies may expand the sample size used here. Second, this study focused on annual reports in measuring the extent of the corporate social responsibility disclosure practices by the selected Islamic banks. Future research might be extended by including other forms of csr disclosure such as websites and others media.

This paper is intended to explore the disclosure level of CSR for IBs in two countries using ISR index developed by [37]. Our sample is 14 Islamic banks from Malaysia and Indonesia. Based on our study ISR index scores show that the extent of disclosure is $26 \%$ that is out of our expectations. Our results are consistent with [10] and [24] who found a gap between expectations and actual disclosure of CSR and conclude that CSRD for IBs is very low. Our finding also shows that there are differences between two countries and it concludes that the rules and pressure from government have impact on the information disclosed by Islamic banks.

\section{REFERENCES}

[1] ICD Thomson Reuters Islamic Finance Development Report, (2014).

[2] A. Wajdi Dusuki, and Humayon Dar. "Stakeholder's Perceptions Of Corporate Social Responsibility Of Islamic Banks: Evidence From Malaysian Economy". Islamic Business Reseacrh Center.pp 389-4197. (2005).

[3] I. Meutia., Menata Pengungkapan CSR di Bank Islam (Suatu Pendekatan Kritis). Jakarta: Citra Pustaka Indonesia. (2010).

[4] C.H Cho., D.M Patten, The role of environmental disclosures as tools of legitimacy: a research note. Acc., Org. and Soc.E 3 (7/8), pp 639- 647. (2007).

[5] R. Haniffa,. \& T.E Cooke, Culture, Corporate Governance and Disclosure in Malaysian Corporations, Ab. 38 3, pp.317-349. (2002).

[6] B. Maali., P.Casson, \& C. Napier, "Social Reporting by Islamic Banks". Ab. 142 2, pp 266-289. (2006). 
[7] M . A . El-Gamal, Islamic Finance: Law, Economics, and Practice, Cambridge

University Press, New York, NY. (2006).

[9] M . T . Usmani, An Introduction To Islamic Finance. Idaratul Ma'arif, Karachi. (1998).

[10] R . Haniffa, and M. Hudaib. "Exploring the Ethical Identity of IB via communication in Annual Reports," J of Bus Eth, 76 1, pp 97-116, (2007).

[11] A. Al-Mograbi. The Social Responsibility of Islamic Banks. International Institute of Islamic Thoughts. (1996)[12] N. Baydoun, and R. Willet. Islam and accounting: Ethical issues in the presentation of financial information. Acc Comm and Fin: The Islamic Perspective. 1 1, pp.1-25, (1997).

[13] M.K. Lewis. 'Islam and Accounting' Acc For, 25 2, pp 103-27, (2001).

[14] S. Hassan. "Corporate Governance Practices of Shariah Islamiah Approved and Shariah Islamiah Non-Approved Companies:Does it matter?", Paper presented at IIUM International Accounting Conference 3, 26-28 June, Kuala Lumpur, (2006).

[15] Bursa Malaysia. The Islamic Capital Market. Kuala Lumpur: Bursa Malaysia. Available at Belal, A., O. Abdelsalam, and S. Nizamee, 2014, "Ethical Reporting in Islami Bank Bangladesh Limited (1983-2010)," J of Bus Eth, DOI 10.1007/s10551-014-2133-8. (2007).

[16] R . Haniffa. "Social Reporting Disclosure-An Islamic Perspective", Ina Mgt \& Acc R 12 pp.128-146.(2002).

[17] R. Gray., R. Kouhy. and S. Lavers. "Corporate social and environmental reporting: A review of the literature and a longitudinal study of UK disclosure", Acc. Au and Acc. 8 2, pp. 47-77. (1995).

[18] C. Deegan., M. Rankin., and P. Voght. "Firms' disclosure reactions to major social incidents:Australian evidence", Acc For 241 pp. 101-130. (2000).

[19]A. Ullmann. "Data in search of a theory: a critical examination of the relationships among social performance, social disclosure, and economic performance of US firms", Ac of Mgt Rev, 10 3. pp. 540-557. (1985).

[20] R. Gray., D. Owen., and C.A. Adams. Accounting and Accountability: Changes and Challenges in Corporate Social and Environmental, Prentice-Hall Europe, London. (1997).

[21] R. Othman., A.M. Thani., E. K. Ghani. Determinants of Islamic Social Reporting Among Top Shariah-Approved Companies in Bursa Malaysia. Res J of Int Stu 12 (October). (2009).

[22] M. Sulaiman. Islamic corporate reporting: Between the desirable and the desired. Research Centre. IIUM Publication. (2005).

[23] M. Zain. "Corporate social reporting in Malaysia: The Current State of the art and Future Prospects", Dissertation for the Degree of Doctor of Philosophy, University of Sheffield. (1999).

[24] A . Hassan., S.S. Harahap. "Exploring corporate social responsibility disclosure: The case of Islamic banks". Intl J of Is and Mid East Fin and Mgt. 33 pp 203-227. (2010).

[25] E.R.Gray. and J.M.T. Balmer. "The corporate brand: a strategic asset." SAM: Mgt in Prac. 4. pp 1-4. (2001)

[26] A. Rahman. Islamic microfinance: An ethical alternative to poverty alleviation. Humanomics, 26 4, 284-295. (2010).

[27] J. A Mohammed. "Corporate Social Responsibility in Islam". PhD work under Auckland University of Technology, New Zealand. (2007).

[29] Z.A. Aribi. and S. Gao. Corporate Social Responsibility Disclosure: A Comparison Between Islamic And Conventional Financial Institutions. J of Fin Rep and Acc. 82 , pp. 72-91. (2010). 
[30] S. Farook., M.K. Hassan., R. Lanis. Determinants Of Corporate Social Responsibility Disclosure: The Case Of Islamic Banks.. J of Is Acc and Bus R. 2 2, pp114-141. (2011).

[31] A . R. Belal.. O Abdelsalam. \& S . S . Nizamee. "Ethical reporting in Islamic bank Bangladesh limited (1983-2010)”. J of Bus Eth. 129 ,pp 769-784. (2014).

[32] R. Kamla., H.G. Rammal. Social reporting by Islamic banks: Does social justice matter?. Acc Au Acc J. 26 6. pp 911-945. (2013).

[33] H.K. Farag. and K. Mallin. Corporate Social Responsibility and Financial Performance in Islamic Banks. J of Ec Behav \& Org 103, pp S21-S38. (2014).

[34] Z.A. Aribi. An Empirical Study of Corporate Social Responsibility and Its Disclosure in Islamic Financial Institutions. Doctor of Philosophy, Edinburgh Napier University. (2009).

[35] R. Ismail., R.A. Rahman., N. Ahmad. Risk Management Disclosure In Malaysian Islamic Financial Institutions: Pre- And Post-Financial Crisis, The J of Appl Bus R March/April 292 pp 419-431. (2013).

[36] A. B . Carroll. A three-dimensional model of corporate performance, Ac of Mgt Rev 4 pp 497-505. (1979).

[37] R. Othman., \& A.M. Thani, A. M. Islamic Social Reporting of Listed Companies in Malaysia. Int Buss \& Ec R J 3 pp. 135- 144. (2010). 